\title{
分布型情報を導入した全球氷河モデルHYOGA2の 開発とヨーロッパ地域における検証 DEVELOPMENT AND VALIDATION OF A GLOBAL GLACIER MODEL HYOGA2 WITH DISTRIBUTED GLACIER INFORMATION OVER EUROPE
}

\author{
平林由希子 1 ・鼎信次郎2 \\ Yukiko HIRABAYASHI and Shinjiro KANAE \\ 1正会員 博士（工学） 東京大学 大学院工学系研究科 准教授（干113-8656 東京都文京区弥生2丁目 \\ 2正会員 博士（工学） 東京工業大学 大学院情報理工学研究科 准教授（广152-8552 東京都目黒区大 \\ 岡山2丁目12-1)
}

\begin{abstract}
Water from small glaciers and ice caps are sensitive against the ongoing global climate change. However, previous researches have been estimated current water resources from glaciers based on areaweight method of available mass balance observations. It is therefore difficult to estimate the future volume change of glaciers due to the lack of available data. This paper reports our latest effort to develop a global glacier model that can be coupled with global hydrological and land surface models by including individual glacier inventory data in a distributed way. Simulation result over European small glaciers showed that the newly developed model successfully replicates average mass balance obtained from available observation-based estimates, indicating the advantage of new model which includes detail location and area distribution of glacier inventories, comparing to the original glacier model assuming one large glacier within each 0.5-degree grid. Sensitivity test revealed that the calculation excluding small glaciers within 0.5-degree grid in a random manner shows similar mass changes, indicating the potential method to save calculation cost of the new model. Preliminary experiment using warming climate scenario by a climate model showed that the new model has lower climate sensitivity than that of the previous model due to the loss of small glaciers at low altitude.
\end{abstract}

Key Words : glacier, mass balance, water resources

\section{1. 研究の背景と目的}

近年，世界の山岳水河（以降，「山岳水河」はグ リーンランドや南極の水床を除いた陸域の水河を指す) は急激に縮退していることが報告されており ${ }^{1)}$ ，ある地 域では水河からの溶け水の増大による水資源の増加が観 測されている一方で, 近い将来の水河の消失と河川の基 底流量の著しい低下が危惧されており2234)5), 将来の水 河の質量変動とその融解水の変化による水資源量の変動 を把握することは, 重要な研究課題である. また, 将来 懸念されている地球温暖化に伴う水河縮退に伴う海洋へ の淡水供給の増加は，昇温による海水膨張と並び将来の 海水準上昇に一定の寄与をすると考えられており ${ }^{6)}$, 過 去から将来の水河の質量変動や, 水河から海へ流出する
淡水量を，広域かつ定量的に推定することも重要である. 一方，質量収支の変化が観測されている水河は，約 16 万個とも言われる世界の山岳水河のうちの300地点にも 満たず, 数十年単位の継続的な質量観測が行われている 水河は約 30 程度である. そのため, 山岳水河からの融解 水が河川流量へ及ぼす影響が算定されている水河は, ヨーロッパアルプスやアメリカ，北欧などの観測データ が揃っている限られた一部の地域の水河だけであり，大 陸規模の水河の質量変化と海への淡水供給量の総量の推 定は，既存の質量収支観測データから地域ごとの面積や 気象要素などを勘案した重み付け平均で求められること が多い（たとえばMeier et al，1984 ${ }^{6)}$ ）。

数十 $\mathrm{km}^{2}$ 以上の広域を対象に数值モデルを用いて山岳 水河の質量変化を算定した例としては, Immerzeel et al. $(2010)^{4)}$ やRadic and Hock $(2011)^{7)}$ が挙げられる. 前 
者はアジアの5大河川を対象に, 日単位の降水量, 衛星 データから得られた積雪面積と水河分布, 河川流量から 数值モデルにおける融雪と融水のパラメータを決定し, 氷河起源の水資源が下流の河川流量へ与える影響を算定 している. しかし，この研究では温暖化の前後の気温の 上昇に応じて氷河も水河からの融解水も一定の減少を続 ける傾向を示しており, 降雪量の増加による氷河の涵養 の影響や, 水河の融解に伴う一事的な河川流量の増加な どの時系列の変化などは示されていない．

後者はCogley $(2009)^{8}$ に による個々の水河のインベント リー(WGI-XF) を基礎とし, 月平均気温と月降水量を入力 データとして氷河の質量変動を算定する数值モデルであ るが，観測データを用いた過去の水河質量変動の検証が 不十分であることが問題である. また，この研究では大 陸ごとの山岳水河の質量変化が示されている点が従来の 研究と比べて画期的であるものの, 将来の水河の変化が 水資源へ与える影響を評価するためには，広域の集計量 のみならずグリッドベースなど分布型の水河融解量を算 定することも必要であると思われる.

以上の背景をもとに，著者らは，これまで陸面モデル への結合が可能である全球 0.5 度グリッドで世界の山岳 氷河の質量変動を算定する数值モデルを開発してきた ${ }^{92}$. しかし，この既存の全球水河モデルHYOGAは0.5度グリッ ド内の複数の水河の質量収支を陽に計算せず，それらを 集計した $1 つ の$ 仮想的な水体を仮定してその質量収支を 計算する構造である. HYOGAで算定された 20 世紀の水河 の質量変動は，質量観測データの広域平均と比べて概ね 妥当な変動を示しているが，気候変化に対する水河の縮 退と進行の感度が観測と比べて低い傾向を示すこと，水 河体積の変化は相対的には求まるものの, 体積の絶対量 の推定ができないことが弱点であり, 将来の気候変動に 伴う水河消失の時期を推定するなどの研究には十分な精 度が無いことが問題であった。

そこで本研究ではHYOGAモデルをさらに発展させ，仮 想的な $1 つ の$ 水体ではなく個々の水河の形状や位置・標 高等の分布型情報をモデルへ与えることにより，個々の 水河の質量収支を計算するモデルの開発に取り組む. 対 象と寸る地域は氷河の位置や形状，過去の質量変化など が水河インベントリーWGI-XF" ${ }^{8}$ に揃っており，かつその 精度も他の地域と比へてて比較的良いと思われるスイスア ルプスと北欧のヨーロッパ地域に存在する7620個の山岳 水河と寸る. この改良により, グリッド内の個々の水河 の涵養や消耗，温暖化による氷河の消失のタイミングな どが算定できるようになり，日単位や月単位などの時系 列で河川流量への水河起源の融解水の寄与がより精度よ く推定できるようになると期待される.

また，全ての山岳水河を算定する代わりに，ごく小さ い氷河は統計的に選出寸ることによってモデルの計算時 間を短縮する方法を試し，HYOGA2の全球一の適用可能性 についても考察を行った. 最後にHYOGA2が新たに氷河の
体積の絶対量を推定できるようになった利点を活かし， 将来気候が温暖化した際に氷河が消失する数とタイミン グについての試算を紹介する.

\section{2. 全球水河モデルHYOGA2}

\section{(1) モデルの概要}

本研究は既存の全球水河モデルHYOGAを基礎とし， 0.5 度グリッド内に存在する個々の水河が算定できるように 改良を加えたHYOGA2の開発を行った．モデルの時間ス テップは日単位，入力データは氷河の分布型情報（緯 度・経度, 最高・最低標高, 長さ, 面積の初期值）と日 単位の地表平均気温と降水量であり，日単位の時間ス テップで50mの標高帯分布ごとに氷河とその上の雪の質 量収支を計算する.ただし，水の上に 1 年以上残留した 雪は氷の涵養に使われる. 気温は $0.0065^{\circ} \mathrm{C} / \mathrm{m} の 一$ 一定の気 温減率で標高帯ごとに变化させ，地表気温が $2^{\circ} \mathrm{C}$ を境に 降雪と降雨を判別した。この閾值 $\left(2^{\circ} \mathrm{C}\right)$ は, 湿度や地 表気温から降雪と降雨を推定する高度な降水判別手法と 比べて概ね似たような降雪量が推定できる ${ }^{10}$ ことから選 定した．なお，全球への適用性を考慮し，サブグリッド 内の降水は全て同じ值を与えた. 以上の基礎となるモ デルは，観測データの存在する氷河の年質量収支や平衡 線高度が概衩再現できていることが確認されている ${ }^{9)}$.

HYOGAでは0.5度グリッドに含まれる水河の面積を合 計して仮想的な1つの水河を仮定したのに対し, HYOGA2 では水河インベントリーWGI-XFに含まれる個々の水河全 ての質量収支を別個に計算する。 そのためHYOGAの手法 に比べると，0.5度グリッドに含まれる氷河の個数倍だ け計算量が増えるため, 全球では計算コストが約 50 倍程 度多くかかると見積もられる。

また，HYOGAでは水河のタイプに関わらずBahr et al $(1997)^{11)}$ とChen and Ohmura (1990) ${ }^{12)}$ による谷水河のパ ラメータを用いた $1 つ の$ 面積-体積の関係式 (V-A関係式) を適用し，氷河の質量収支計算を行って次の時間ステッ プの体積（V）を更新した後に面積（A）を更新したのに 対し, 本研究では1) 水帽と水帽以外の水河を区別して Radic and Hock $(2010)^{7)}$ による異なるパラメータをV-A 関係式に使用寸ること，2) 新たに氷河の長さパラメータ

（L）を導入して氷河の体積の更新に応じて氷河の長さ を更新し，その長さ情報をもとに氷河の最低標高を更新 するV-A-L関係を用いる，という2点の変更をモデルに適 用した。 これにより, 水河の形状 (山岳水河・氷帽の 別）に応じた $\mathrm{V}-\mathrm{A}$ 関係が反映されると共に，水河の形状 に応じたV-A-L関係に応じて氷河の縮退・拡大のスピー ドが決定されるようになった。

Radic and Hock (2010) 7) もHYOGA2 と同様にWGI-XFを基 礎とする数值モデルを開発したが，彼らのモデルでは36 個の水河質量観測データを用いてモデルの7つのパラ 
表-1 HYOGAとHYOGA2の比較

\begin{tabular}{|c|c|c|}
\hline & HYOHA & HYOGA2 \\
\hline 形状 & $\begin{array}{l}\text { 0.5度グリッド内に1つの谷水 } \\
\text { 河を仮定 }\end{array}$ & $\begin{array}{l}\text { 水河インベントリーWGI-XFより } \\
\text { 個々の水河の情報を導入 }\end{array}$ \\
\hline $\begin{array}{l}V-A \text { 関係 } \\
V=c_{a} A r\end{array}$ & $\begin{array}{l}\text { 全て同じパラメータ } \\
\mathrm{c}_{\mathrm{a}}: 0.2055, \gamma: 1.375\end{array}$ & $\begin{array}{l}\text { 谷水河と水帽を区別 } \\
\mathrm{c}_{\mathrm{a}}: 0.2055, \gamma: 1.375 \text { 谷水河 } \\
\mathrm{c}_{\mathrm{a}}: 1.7026, \gamma: 1.25 \text { 水帽 }\end{array}$ \\
\hline 長さ (L) & 初期面積と標高から設定 & $\begin{array}{l}V=c_{1} L^{q} \\
q: 2.2, c_{1}: \text { WGI-XFより設定 }\end{array}$ \\
\hline 融解係数 & $\begin{array}{l}\text { 質量収支観測の長期平均に } \\
\text { 合うようにキャリブレーション }\end{array}$ & HYOGAの0.5度グリッドの值 \\
\hline $\begin{array}{l}\text { キャリブレー } \\
\text { ションパラ } \\
\text { メータ }\end{array}$ & $\begin{array}{l}\text { グリッドごとに5つ: } \\
\text { 雪と水の融解係数、最高・最 } \\
\text { 低標高、初期の水河面積 }\end{array}$ & $\begin{array}{l}\text { 氷河ごとに1つ: } \\
\text { 初期の氷河面積 }\end{array}$ \\
\hline
\end{tabular}

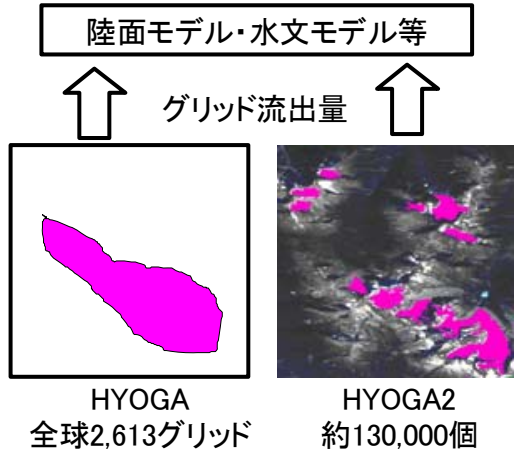

図-1モデルのイメージ．ピンク色が涾河.
メータを決定し，気候や地形からそのパラメータを他の 地域一適用する手法で広域のパラメータを設定して，広 域の水河の計算を行っている. また, Radic and Hock $(2010)^{71}$ はWGI-XFの水河面積を2000年の初期值と仮定し, 2000年以降の温暖化実験を行って広域の水河の融解量を 算定した感度実験の結果のみを示しており, 過去の質量 観測データを用いた過去のシミュレーションの検証など は行われていない，一方のHYOGA2では，以下に述べるよ うに1948年時点の氷河面積の初期值を求め, 最小限のパ ラメータ数でより広域に適用できる構造となっている. 過去数十年のモデル実験も行えるため, 既存の水河質量 観測データを用いた検証を行うことも可能である.

\section{（2）モデルのキャリブレーション}

既存のモデルHYOGAでは，0.5度グリッドごとに1)氷河 面積の1948年の初期值，2)氷河の最低・最高標高，3)雪 ならびに氷のしきい值以上の気温に対する融解係数 $\left(\mathrm{mm} /{ }^{\circ} \mathrm{C} / \mathrm{day}\right)$ に関して, キャリブレーションを行った.

1) は水河インベントリーから得られる水河の面積が観測 された年月日の面積に近くなるように初期值を変える繰 り返し計算をすることによって求める．2）と3）に関して は，対象と寸るグリッドから最も近い氷河のマスバラン スデータが得られた期間の平均と，モデルで計算される 対象グリッドの水河のマスバランスの同期間の平均が近 くなるようにキャリブレーションを行っている.

一方のHYOGA2では個々の氷河を別々に計算するため, 2) はWGI-XFから与えられる最高・最低標高をそのまま用 いる．3）に関しては，ほぼ同じ気候条件であれば水河の 標高やサイズに関わらず雪と氷の融解係数は一定である と仮定して, 既存のモデルHYOGAで求めたグリッドごと の值をそのまま用いることとした，従って新しいモデル では，1）の1948年1月1日時点の水河面積の初期值を繰 り返し計算することで求めるだけであり, その他のキャ リブレーションは行わない.

以上の今回新たに開発を試みたモデルHYOGA2の元のモ デルとの違いの概要と模式図は, 表1と図1に示される.

\section{3. 使用データ}

\section{(1) 気象データ}

本研究ではHirabayashi et al. (2008) ${ }^{13)}$ による1948 年から 2007 年までの全球0.5度グリッドの日降水量と日 平均気温(H08) を気象外力データとしてモデルに与えた。 H08は0.5度グリッドの月平均気温と月降水量の観測デー タを, 統計的に日単位にダウンスケーリングして作成し たものであり, 雨量計タイプごとの降雨と降雪の捕捉率 を用いた補正も行っている ${ }^{10)}$. 使用したデータセットの 基礎となる月平均気温はCRU TS2.0 (1948-2002) ${ }^{14)}$ と GHCN+CAMS $(2003-2007)^{15)}$ であり，GHCN+CAMSのデータは CRU TS2.0との月ごとの気候值（1961-2000）の比を用い て補正したものを用いた. 降水量はGPCC ver. 5の月平均 值を基礎とし，0.5度グリッドの日降水量データが APHRODITE V1003R $1{ }^{16)}$ から得られるグリッドに関しては ダウンスケーリングした日データは用いず，APHRODITE に雨量計捕捉率の補正を適用したものを使用した.

将来の気候データ (GCM) はMIROC-HiのA1B-AR4実験17) を用いた. このシナリオ・GCMを選んだ理由は，世界の GCMの中でも将来の昇温が高く, モデルの感度を試すの に都合が良いからである，GCMのバイアスは，GCMの 1961-2000年 (20C) と同期間のH08データを用いて補正し た. 気温はGCVとH08の月気温の $20 \mathrm{C} の$ 平均の差を各月の 補正值とした. 降水日数はH08の 20 Cの降水日数に, GCM の20Cから2001-2100の将来実験の 20 年ごとの月降水日数 の増減率を乗じて求め, 降水強度は8つのクオンタイル

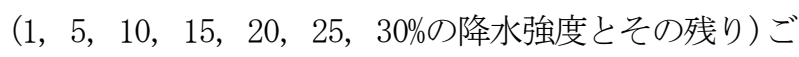
とに20Cの平均のH08とGCMの比を算定して，その比にGCM

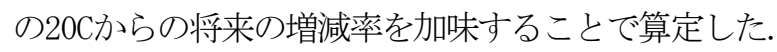

\section{（2）水河データ}

水河モデルに与える山岳水河の位置・長さ, 面積は水 河インベントリー(WGI-XF) ${ }^{8)}$ を使用した. 同データセッ 卜の対象地域（ヨーロッパの2つの矩形領域、60-70N, 5W-33E；43-48N，2W-13E）に含まれる水河の登録数は 
7631であるが，そのうち11は面積情報が存在しないため, 計7620個，合計面積 $5993 \mathrm{~km}^{2}$ の水河がモデルで計算され る. 最高標高もしくは最低標高が得られなかった氷河に 関しては, 最高標高と最低標高の差が1500m と仮定して, 得られない他方の代わりを算定して求める.ただし,

Shuttle Radar Topography Mission (SRTM90)の標高 データを用いて対象の氷河が含まれる0.5度グリッドの 最高標高と最低標高を取得し，作成した最高標高または 最低標高の值がその範囲を超える場合は，グリッド内の 最高標高もしくは最低標高を与えることとした.このよ うな措置を行う必要がある水河は, 全球では約 13 万個の WGI-XF登録データのうち約2000個，本研究の対象地域で は7620個のうちの25個とごくわずかであり，最終的なモ デル算定結果にはあまり影響を与えないと仮定した.

$\mathrm{V}-\mathrm{A}-\mathrm{L}$ 関係を適用寸るためのLの初期值は，WGI-XFの水 河の最大長さ $\left(\mathrm{L}_{\max }\right)$ を用いた。 しかし， $\mathrm{L}_{\max }$ がインベント リーに登録されている氷河は限られており，対象地域の 7620個の水河のうち1549個しかない，そのため, 最高標 高・最低標高と水河の $\mathrm{L}_{\max }$ が得られる水河において最高 標高と最低標高の差と $\mathrm{L}_{\max }$ の比の平均值を求め, その值

（0.004188）を最高標高と最低標高の差に掛けることで, $\mathrm{L}_{\max }$ を推定した. $\mathrm{L}_{\operatorname{ma}}$ の精度は氷河の位置や形状によりま ちまちであるが，その誤差によるモデルの不確実性より も，面積に対寸る標高差の情報でも水河の形状と前進・ 後退のスピードが間接的に代表できることの利点が大き いと考え, 推定した $\mathrm{L}_{\text {ma }}$ を用いることとした.

\section{4. 結果}

\section{（1）HYOGA2によよる質量収支計算}

まず，新たに改良を加えた氷河モデルHYOGA2の挙 動を既往のモデルHYOGAと比較した。
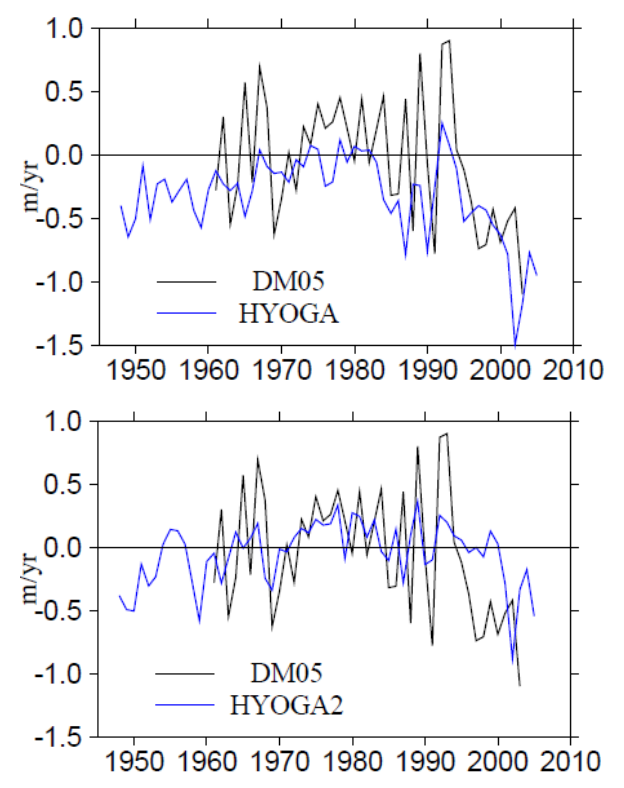

図-2 対象地域の平均の年平均質量収支 $[\mathrm{m} / \mathrm{yr}]$
図2は対象地域の全水河の平均の質量収支を示寸。黒 線が観測された質量収支データの面積重み付け平均から 推定された值 (DM05; Dyurgerov and Meier, 2005 ${ }^{18)}$ ), 青線がモデルの出力結果である．ただし，DM05の作成に 用いられた水河の質量収支観測データは対象地域の水河 全体のごく一部であり，DM05の值が必ずしもヨーロッパ 地域の水河の平均の質量収支を代表しているとは限らな い. 従って対象地域の全水河を計算しているHYOGAや HYOGA2 とDM05を比較する際には，注意が必要である.

新旧のモデルで同じ融解係数のパラメータを用いてい るため, HYOGAとHYOGA2の平均的な質量収支はあまり変 わらないように見える. しかし，HYOGA2は1970年代後半 から1990年代にかけての正の質量収支が再現できるなど， 経年の変動についてDM05に近くなっていることがわかる. また，HYOGA2はHYOGA と比べて質量収支の年々変動の振 幅が大きくなり, よりDM05の変動幅に近くなっている. この理由は氷河の形状や位置をHYGA2に取り入れたこと により，標高が低い場所に位置する氷河や，面積に比心 て標高方向に長細い水河など気温や降水量の変動に対す る質量収支の変動が大きい水河の変動が反映されやすく なったためであると思われる.

一方HYOGA2では，DM05に見られる2000年前後の大きい 負の質量収支は見られない. そもそも1960年代以前や 1990年以降は DM05の作成に使われた観測データの数が かなり限られるため, 面積重み付け平均で求めた推定值 は限られた観測の值を反映して本来の領域平均值よりも 過大や過小になりや寸い. HYGA2はヨーロッパ地域の全 水河を面積重み付け平均していることから, デー夕数の 限られる期間のDM05とは必ずしも一致しないであろう。 ただし 2000 年以降の気象データの質が悪いこと ${ }^{13)}$ は, 2000年以降のHYOGA2の算定值に誤差をもたらしている可 能性があると思われる. 観測が比較的多く存在する 1970-1990年代の平均的な質量収支と変動がDM05 と近く なっていることから，HYOGA2の妥当性を評価したい．

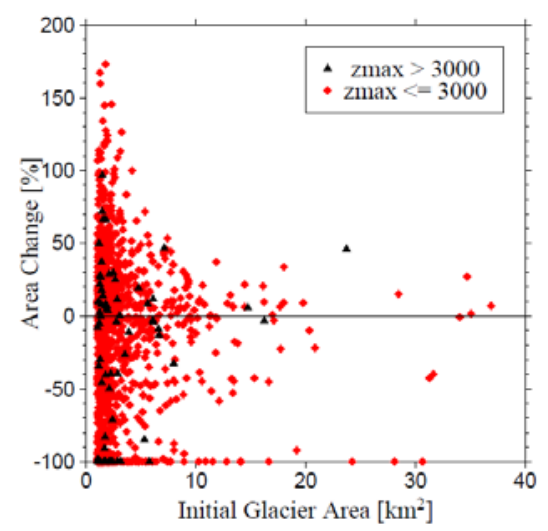

図-3ＨYOGA2による1948-2007の水河面積変化.

図3はHYGA2による各水河の面積の変化を示寸，横軸は シミュレーションの初期面積を示す. 面積が小さい $\left(<10 \mathrm{~km}^{2}\right)$ 氷河はサンプル数が多く, 面積の増減が50\%以 
上の水河も数多く存在することが分かる. 一方，面積が $20 \mathrm{~km}^{2}$ 以上の水河の増減の幅は概水 $\pm 20-30 \%$ 前後である この理由は, 水河が小さいと水河の高さが50mの標高帯 では解像することが困難で気温や降水などの変化に対す る氷河の増減一の感度が高くなるためである. また，水 河の標高による増減の傾向に顕著な違いは見られなかっ た（図3では最低標高 $Z_{\max }$ を3000mで分類した例を示す）。

なお，図3では氷河が100\%消失している所もいくつか 見られる. しかしHYOGA2では個々の水河に対して融解係 数などのキャリブレーションをしておらず，0.5度グ リッド平均の気温データを入力として $50 \mathrm{~m} の$ 標高帯ごと に一定の気温減率で求めた気温を与えたことによるバイ アスがあるため, 個々の水河の消失や増加が必ずしも現 実のタイミングとぴったり一致しているとは限らない.

\section{（2）小さい水河を統計的に選出して計算する手法}

以上のように，HYOGA2は観測值から推定した質量 収支と比べてより現実的な変動を示しており，既存のモ デルHYOGAより優れていることが判明した. しかし， HYOGAでは全球で2613個の0.5度グリッドの水河を計算 寸れば良かったのに対し，HYOGA2で約13万個の全球 の水河を計算する為には，その50倍の計算時間がかかる. 将来の水河の算定を行う際に, 複数のGCMシナリオ 複数の温室効果ガスシナリオの全てについて算定するた めには，結果をほとんど変えない範囲でモデルの計算速 度を効率良く上げることも必要である.

そこで，WGI-XFに登録されている氷河のうち，ある しきい值よりも小さいものに関しては，個々の0.5度グ リッドに含まれるものをランダムに抽出して代表の質量 変動を計算し，残りの小さい水河の質量収支は面積重み 付けで算定するという，統計的な選択手法を試した。 小 さい水河の代表を 0.5 度グリッドごとに選ぶ際には乱数 を発生させてランダムに選出したが，モンテカルロ式に 同様の作業を複数回試しても結果はほぼ同じであったた め，ある1つの選定の組み合わせの結果を図4に示寸。そ れぞれ，黒線が対象地域の全水河7620個を計算した HYOGA2の結果（図1の青線と同一），赤が初期面積が $0.5 \mathrm{~km}^{2}$, 緑が $1 \mathrm{~km}^{2}$, 青が $2 \mathrm{~km}^{2}$ 以下の小さい水河の代表开 ンプルのみを計算して平均を作成した際の結果を示す.

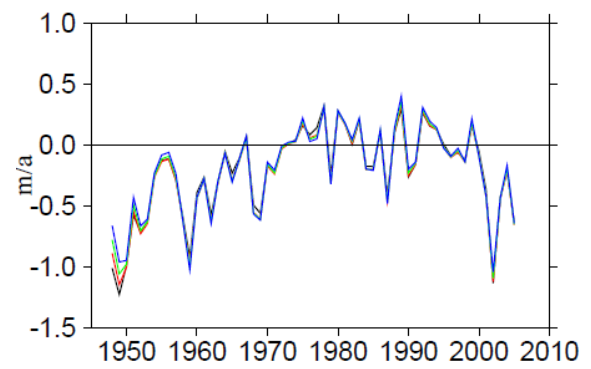

図-4 図1と同様，ただし閾値以下の水河を統計的に選出し た結果との比較（本文参照）。線の色は表2の分類に対応.
表-2 小さい水河を統計的に選択する際のしきい值と, しきい值以上の水河の面積ならびにサンプル数

\begin{tabular}{|c|c|c|}
\hline しきい值 $\left(\mathrm{km}^{2}\right)$ & 総面積 $\left(\mathrm{km}^{2}\right)$ & 氷河の数 \\
\hline \hline なし & 5994 & 7620 \\
\hline$>0.5$ & 5113 & 1972 \\
\hline$>1$ & 4567 & 1173 \\
\hline$>2$ & 3789 & 613 \\
\hline
\end{tabular}

図4より，小さい水河をランダムに選出して計算を 行っても，対象領域の平均の質量収支については，ほと んど差異が無いことがわかる．たとえば $1 \mathrm{~km}^{2}$ 未満の水河 で行った場合（緑），約7分の1の数の水河，面積にして 約 $25 \%$ 少ない水河に対してしか質量収支計算を行わなく とも, 結果がほとんど変わらないということが示された。

\section{（3）温暖化実験に対するHYOGA2の感度}

最後にバイアス補正したGCM, MIROC-Hiを入力として 与えた温暖化実験の結果を紹介寸る.
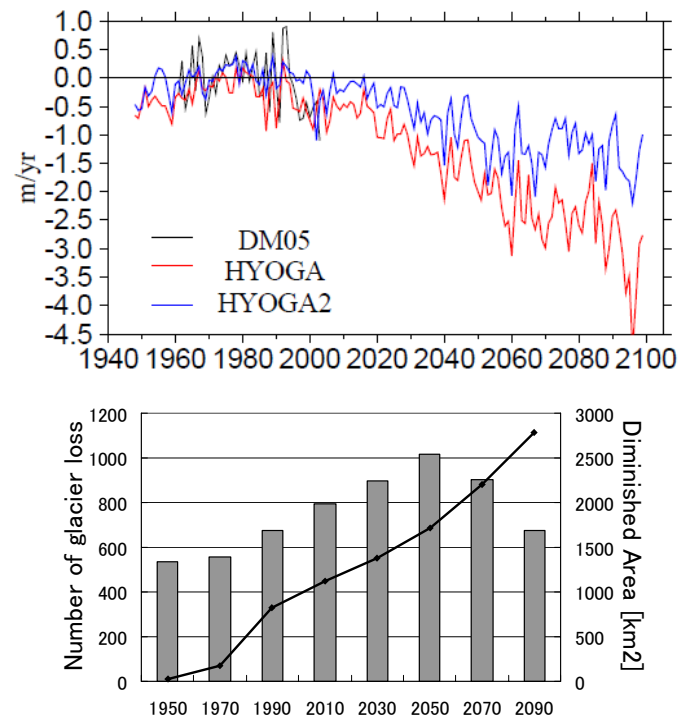

図-5 MIROC-Hiを与えた温暖化実験. 上が将来の質量収支 変化，下は消失する水河の個数（棒）と積算の面積（折れ線）

図 5 上より，氷河の質量収支はHYOGA2の方が HYOGAよりも昇温に対する減少が低いことが示された。 この理由は，HYOGAは大きい1つの水体を仮定してい るために同じ合計面積に対して相対的な体積が大きくな るため，温暖化しても氷河が消失しないで標高の上方に 残存するためである. HYOGA2では分布型の水河情報 を入れて氷河の体積の絶対量をモデルに導入したため, 気候が温暖化すると標高が低い場所に位置している水河 から融解して消失してゆく. 図5上は面積重み付け平均 で計算しており，消失した氷河はHYOGA2の質量収支 の結果に影響しなくなる為，平均の質量収支の值は HYOGA2の方がHYOGAよりも大きくなることは妥当な 結果である. また, 氷河からの融解水についても, HYOGA2からの淡水流出量はHYOGAよりも少なくなる （図無し）。このように各水河の分布情報, 面積ならび 
に体積の絶対量をモデル内に取り入れることにより, 水 河からの水資源を定量的に議論することが可能となった。 また，ヨーロッパの水河の約半数は21世紀の半ば頃, 約8割は2100年までに消失する結果となった（図5下）。 氷河消失のピークはMIROC-Hiの昇温率が最も高い20402060年である. MIROC-Hiは21世紀の北半球高緯度の昇 温が大きいシナリオではあるが，小さい氷河の質量収支 計算を行う際の標高帯の刻み幅が適切であるか，氷河の 縮退に伴う水河の標高上方への移動によるフィードバッ クがきちんと効いているかなど，HYOGA2の気候感度 についてはさらに詳細な解析が必要であると思われる.

\section{5. まとめ}

本研究では，氷河インベントリーを利用して個々の水 河の特徵を導入しながらも広域の水河を対象に質量計算 を行う新しいモデルHYOGA2を開発した。ヨーロッパ 地域の水河を対象に既往のモデルとの比較を行ったとこ ろ， 0.5 度グリッド内の水河について分布型の情報を水 河インベントリーからモデルに導入することにより，よ り観測データからの推定值に近い質量収支の年々変動が 再現できることが判明し，その有用性が確認できた．小 さい水河を統計的に選択寸ることにより計算時間を短縮 しても結果にあまり大きい影響を与えないことも示され， HYOGA2を全球一適用寸る可能性が示唆された.

また，HYOGA2に温暖化実験データを与えた試算か ら, 将来の地表気温の温暖化に対する水河の融解スピー ドと消失を時系列で示した. 今後は他の地域を対象にし た実験や，他のGCMを用いた温暖化実験を行い，より 詳細な解析を行っていく予定である.

謝辞 : 本研究は最先端・次世代研究開発支援プロジェク 卜「山岳水河の融解が世界の水資源逼迫に与える影響」 ならびにJST/CRESTの研究課題「世界の持続可能な水利 用の長期ビジョン作成」から支援を受けた.

\section{参考文献}

1) Parry, M. L. and Intergovernmental Panel on Climate Change Working Group II: Climate Change 2007: Impacts, adaptation and vulnerability: Contribution of Working Group II to the fourth assessment report of the Intergovernmental Panel on Climate Change, Cambridge University Press, 2007.

2) Jansson, P., Hock, R. and Schneider, T.: The concept of glacier water storage - a review, J. Hydrol., Vol.282, pp.116-129, 2003.

3) Piao, S., Ciais, P. Huang, Y., Shen, Z., Peng, S., Li, Junsheng, Zhou, L. Liu, H. Ma, Y. ding, Y. Friedlingstein, P. Liu, C. Tan, K. Yu, Y. Zhang, Y. and Fang, J.: The impacts of change on water resources and agriculture in China, Nature, Vol.467, pp.43-51, 2010.

4) Immerzeel, W.W., van Beek, L.P.H. and Bierkens, F.P.: Climate change will affect the Asian water towers, Science, Vol.328, pp.1382-1385, 2010.

5) Kaser, G., Grosshauser, M. and Marzeion, B.: Contribution potential of glaciers to water availability in different climate regions, PNAS, Vol47, pp.20223-20227, 2010.

6) Meier, M.F: Contribution of small glaciers to global sea level, Science, Vol.226, pp.1418-1421, 1984.

7) Radic, V. and Hock, R.: Regionally differentiated contribution of mountain glaciers and ice capst to future sea-level rise, Nature Geo., Vol.4, pp.91-94, 2011.

8) Cogley, J.G.: A more complete version of the world glacier inventory, Ann. Glaciol., Vol.50, pp.32-38, 2009.

9) Hirabayashi, Y., Döll, P. and Kanae, S.: Global-scale modeling of glacier mass balances for water resources assessments: glacier mass changes between 1948 and 2006, J. Hydrol., Vol.390, pp.245-256, 2010.

10) Hirabayashi, Y., Kanae, S., Masuda, K., Motoya, K. and Döll, P.: A 59-year (1948-2006) global near-surface meteorological data set for land surface models. Part II: Global snowfall estimation, Hydro. Res. Lett., Vol.2, pp.65-69, 2008.

11) Bahr, D.B, Meier, M.F. and Peckham, S.D.: The physical basis of glacier volume-area scaling, J. Geopphys. Res., Vol.102, pp.2035520362, 1997.

12) Chen, J. and Ohmura, A.: Estimation of Alpine glacier water resources and their changes since the 1870s, IAHS Publ., Vol.193 (Symposium at Lausanne 1990- Hydrology in Mountainous Regions I), pp.127-135, 1990.

13) Hirabayashi, Y., Kanae, S., Masuda, K., Motoya, K. and Döll, P.: A 59-year (1948-2006) global near-surface meteorological data set for land surface models. Part I: Development of daily forcing and assessment of precipitation intensity, Hydro. Res. Lett., Vol.2, pp.36-40, 2008.

14) Mitchell, T.D. and Jones, P.D.: An improved method of constructing a database of monthly climate observations and associated high-resolution grids, Int. J. Climatol., Vol.25, pp.693712, 2005.

15) Fan, Y. and van den Dool, H.V.D.: A global monthly land surface air temperature analysis for 1948-present, J. Geophys. Res., Vol.113, doi:10.1029/2007JD008470, 2008.

16) Yatagai, A., Arakawa, O. Kamiguchi, K., Kawamoto, H., Nodzu, I. and Hamada, A.: A 44-year daily gridded precipitation dataset for Asia based on a dense network of rain gauges, SOLA, Vol. 5, pp.137-140, doi:10.2151/sola.2009-035, 2009.

17) K-1 model developers: K-1 coupled model (MIROC) description, Technical report, CCSR, Univ. Tokyo, Tokyo, Japan, 2004.

18) Dyurgerov, M.B. and Meier, M.F.: Glaciers and the Changing Earth System: A 2004 Snapshot, Occasional Paper No.58, Institute of Arctic and Alpine Research, Univ. Colorado, USA, 2005.

(2011.9. 30受付) 